\title{
小学生を対象としたロボット教室の実践と考察
}

\author{
大西 義浩 ${ }^{* 1}$, 森 慎之助 ${ }^{* 1}$

\section{Practices and Considerations of Robotics Class for Elementally School Students} \\ Yoshihiro OHNISHI ${ }^{* 1}$ and Shinnosuke MORI \\ ${ }^{* 1}$ Ehime Univ. Faculty of Education \\ Bunkyocho 3, Matsuyama, Ehime, 790-8577 Japan

\begin{abstract}
We have organized a robotics class for elementally school students as an event of JSME Robotics and Mechatronics Division. LEGO mindstorms NXT was used as the learning tools. This paper gives the reports of this event and the consideration of the questionnaires about interests of elementally school students.
\end{abstract}

Key Words : Robot, Sensor

\section{1. 緒言}

日本機械学会ロボットメカトロニクス部門の第 6 地区（四国地区）技術委員会のイベントとして，愛媛大学教 育学部技術教育で小学生を対象にロボット教室を開催する機会を得た. 本稿では, 実施したイベントの概要を報 告し, 小学生のロボットに対する興味・関心に関して行ったアンケート調査の考察を行う.

\section{2. ロボット教室の概要}

ロボット教室は平成 25 年 1 月 26 日 13:00 16:00に行い, 小学生 3 年生から 6 年生の 19 名が参加した. 内訳は 6 年生 : 6 名, 5 年生 : 3 名, 4 年生 : 6 名, 3 年生 : 4 名で, 性別は男子 18 名, 女子 1 名である. 基本的に 2 名で ペアを組ませ 10 チーム（1チームだけ 1 名）を作った. ペアの作り方は，兄弟・知り合いの場合はそのままでぺ アを組ませ，単独で参加している場合は任意でペアを組ませた.

教室の内容は，マインドストームNXT のプログラミングを行い，2名に 1 台のロボットとノート PC を用意し た. 最初の 90 分にプログラムを作成するソフトウェアの使用法について説明した上で，つぎの 60 分は課題を与 え，試行錯誤させるようにプログラムを作成させ，最後の30 分は競技大会を行った. 小学生のやる気を持続させ るために，競技大会で優勝した組には景品があると告知しておいた．最後にこのロボット教室についてのアンケ ートを実施した.

課題内容は,「ロボットをスタートさせ障害物を S 字に抜ける.壁まで進み超音波センサを使用して壁より $25 \mathrm{~cm}$ 以内で一時停止する．つぎに，反転して黒丸まで進ませ，光センサを使用し，ライントレースしてゴールする.」 である. プログラミングのポイントは, 最初の S 字部分はセンサを使わないフィードフォワード制御, 超音波セ ンサを用いるフィードバック制御，最後のライントレース部分での試行錯誤などである.コースの概要を図 1 に 示す.

\section{3. アンケート結果の考察}

参加の動機を回答させたところ「ロボットが好きで自分で行きたいと思った」が 11 名で最も多く, 続いて「小 さい時レゴブロックで遊んでいた」，「友達に誘われた」であった.このような不特定詨象者の催しに関しては, 子どもたちの素直な感情が自主的な参加につながったことがわかる.

\footnotetext{
${ }^{{ }^{*} 1}$ 正員, 愛媛大学 (广790-8577 愛媛県松山市文京町 3 番)

E-mail: ohnishi@ehime-u.ac.jp
} 


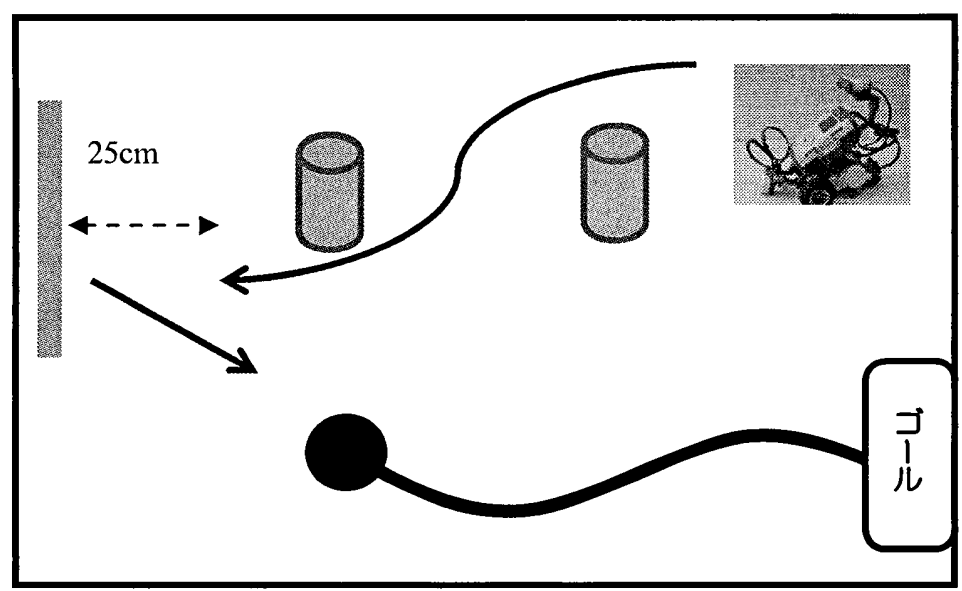

図 1 課題の内容

「自分にとってどのようなロボットがいたらよいか」を記述式で回答させると, 半数の小学生が「人間を手伝 ってくれるロボット」と書いていることからもわかる.これは, 地震・火災・原発事故などによる災害人命救助, 高齢者・障害者の介護の必要性や家庭生活における炊事・掃除・洗濯など家事の大変さなどにロボットが活躍す ることを期待していると推察される.

「ソフトウェアの使用法の理解」に関する質問には，3 年生の 1 名が否定的に回答した以外は，肯定的であっ た. ソフトウェア自体がコーディングを行うことなく視営的にブロックをくみ上げていく方式なこと，小学生向 きにマニュアルを作成し，さらに大学生のサポートがあったことなどが，ここで戸惑う参加者は少なかったこと につながったと思われる.

「課題の難易度」については 18 名の小学生が否定的に回答した. 今回の課題で最も難しいと思われるのは光セ ンサを使用したライントレースの部分である. 結果として，この課題をクリアできたのは 10 チーム中， 2 チー ムであった. 残りは壁にまで進み一時停止，または反転までクリアできていた. この結果から，小学生を対象に プログラム作成を行わせるような学習は可能であると思われる．また，「作成したプログラムの評価」では 7 名の 小学生が否定的に回答した．これは，ロボットの動きのイメージと実際にプログラムを作成してロボットを動か してみた後のずれから自己評価を峳しくしたものと思われる.

今回のロボット教室の満足の度合いについては, 全員の小学生が肯定的に回答した. また, 次回のロボット教 室の期待の度合いについても全員の生徒が肯定的に回答した．課題内容についてはほとんどの生徒が難しいと回 答し，作成したプログラムも 3 割の小学生が不満足にも関わらず，ロボット教室の満足および期待の度合につい て全員が肯定的であることは，ロボットへの興味・関心が高く，課題解決への探究心の高さがかなり強いと考え られる.

\section{4. 結言}

本稿では，ロボットメカトロニクス部門のイベントとして実施したロボット教室の概要とアンケート結果につ いて報告した. 上記では深く触れなかったが, この教室には愛媛大学教育学部技術教育専修の 2,3 回生 8 名がT Aとして協力した. 将来，小学校や中学校の教師を目指している学生の教育体験機会の提供につながっていると いう面もある．本報告での結果を分析して，今後も機会があれば，同樣のイベントを実施し，改善につなげたい と考えている. 